\title{
Intestinal mucin distribution in the germ-free rat and in the heteroxenic rat harbouring a human bacterial flora: effect of inulin in the diet
}

\author{
BY N. FONTAINE 1 , J. C. MESLIN 1 , S. LORY² AND C. ANDRIEUX \\ ${ }^{1}$ Laboratoire de Nutrition et Sécurité Alimentaire and ${ }^{2}$ Unité d'Ecologie et Physiologie du \\ Système Digestif, INRA CRJ, 78352 Jouy-en-Josas Cédex, France
}

(Received 2 February 1995 - Revised 22 September 1995-Accepted 11 October 1995)

\begin{abstract}
A colorimetric method was used on water-soluble mucin extracted from mucosal scrapings and contents of the caecum and the colon of five germ-free (GF) rats and five heteroxenic (HE) rats harbouring a human flora (GF rats associated with a human flora). These rats were fed on a diet containing either $100 \mathrm{~g}$ sucrose $/ \mathrm{kg}$ or $100 \mathrm{~g}$ inulin/kg. Histological stains, periodic acid-Schiff, alcian blue pH 2.5 and alcian blue $\mathrm{pH} 0.5$ were used to discriminate between neutral, acidic and acidic sulphated mucins respectively. Spectrocolorimetric assays led to a calculated absorbance value for $1 \mathrm{mg}$ of the initial mucin extract. Each mucin type was compared between treatments. The caecal contents of GF rats contained more acidic mucin than sulphomucin, which was present in the same proportion as neutral mucin. Their colonic contents contained more acidic mucins than sulphomucin, which in turn was more abundant than neutral mucin. Their caecal mucosa mucin distribution differed from that of the contents: very little acidic mucin was present and neutral and sulphomucin proportions were of the same order of magnitude. Inulin increased the amount of neutral mucin in the caecal contents and of sulphated mucins in the colonic contents and increased the amounts of neutral and acidic mucins in the caecal mucosa. Mucin distribution in the HE rats was very different from that in the GF rats: the caecal contents contained a high proportion of acidic mucins and very little sulphomucin. The same distribution of mucins was observed in the colonic contents. The caecal mucosa contained less acidic mucin and more sulphomucin than the caecal contents. Inulin decreased acidic mucins and increased sulphated mucins in the caecal contents and increased neutral and sulphated mucins in the colonic contents. Inulin increased sulphomucin in the caecal mucosa and decreased acidic mucin in the caecal and colonic mucosas. The very low amount of mucin that was recovered in the colonic mucosa suggests that, in the presence of the bacterial flora and associated with inulin in the diet, mucin was extensively released from the mucosa to the colonic lumen. This might be related to the bacterial metabolites produced.
\end{abstract}

Mucins : Intestine: Bacteria: Inulin

Mucin glycoproteins can be classified into three groups on the basis of their histochemical staining: neutral mucins, sialic acid-containing mucins and ester sulphate-containing mucins (Filipe, 1979). The presence of sulphate and sialic acids on the carbohydrate chains confers to the intestinal acidic mucins physicochemical properties different from those of neutral mucins, resulting in higher viscosity and acidity (Allen et al. 1982). These acidic mucins increase the mucus potential to resist attack by bacterial enzymes (Rhodes, 1989). In man, neutral, acidic and sulphated mucins vary widely in various diseases (Filipe, 1979; Smith \& Podolsky, 1986). In animals, age and diet affect the composition of the intestinal mucins (Satchithanandam et al. 1990; Turck et al. 1993). Dietary fibres have been shown to alter intestinal mucus composition qualitatively and/or quantitatively (Cassidy $e t$ al. 1981; Huang et al. 1990) either by a mechanical effect on the intestinal mucosa (Komai \& 
Kimura, 1980; Ecknauer et al. 1981; Southon et al. 1985; Dirks \& Freeman, 1987), or by the bacterial fermentation metabolites acting on the mucosal metabolism. End-products of fermentation are mainly short-chain fatty acids (SCFA), which may induce local osmolality variations resulting in mucus secretion (Sakata \& Engelhardt, 1981). Furthermore, dietary fibres induce the activity of glycolytic enzymes, which could alter mucin degradation (Salyers et al. 1977).

In a previous paper, by using a technique based on the histochemical characteristics of the mucin types we showed, in the rat, that the bacterial flora modified the goblet-cell mucin distribution in the caecal and colonic mucosas (Meslin et al. 1993). Supplementing the diet with poorly digestible and fermentable carbohydrate was without effect on caecal mucin composition in the germ-free (GF) rat, but modified goblet-cell number and mucin types in conventional and heteroxenic (HE) rats. Studies have shown that human flora inoculated into GF rats keeps its major properties, specific bacterial populations, enzymic activities and fermentative profile (Andremont et al. 1985; Cole et al. 1985; Mallett et al. 1987; Debure et al. 1989; Andrieux et al. 1991). The HE rat mimetic model obtained is more valuable than the conventional rat for studying colonic fermentation in man. Comparing GF rats with $H E$ rats provides information on the action of the intestinal microbial flora.

The aim of the present study was to investigate the effect of a bacterial flora on the proportions of mucin types both in the luminal contents and in the mucosa of the caecum and colon in the rat. The diet was supplemented with inulin $(100 \mathrm{~g} / \mathrm{kg})$, in order to increase bacterial metabolite production. Inulin occurs in cereals, onions, artichokes and other compositae (Bacon \& Edelman, 1951). It is composed of 15-30 $\propto 1-2$ fructose units, and is thus indigestible by endogenous enzymes and completely fermented by the microbial flora (Nilsson \& Björck, 1988; Nilsson et al. 1988; Rumessen et al. 1990). In HE rats the fermentation of inulin lowers the $\mathrm{pH}$ of caecal contents and increases SCFA concentrations (Andrieux et al. 1991), particularly butyrate, which has a trophic effect on the intestinal mucosa (Sakata, 1987).

\section{MATERIALS AND METHODS}

\section{Animals}

Male GF and HE inbred F344 rats (2 months old) were used. HE rats were obtained by inoculating GF rats with human faecal flora. Human faeces provided by a methanoproducer were diluted 1:20 (w/v) with saline $(9 \mathrm{~g} \mathrm{NaCl} / \mathrm{l})$ in an anaerobic chamber; $1 \mathrm{ml}$ of this dilution was inoculated orally twice during $24 \mathrm{~h}$. Animals were cared for in accordance with the guidelines set out by our institute and adapted to conform to those established by the Canadian Council for Animal Care (Ottawa, Ontario, 1984). Temperature and relative humidity of the animal room were controlled $\left(21 \pm 2^{\circ}, 60 \pm 5 \%\right.$ respectively). The lighting schedule was also controlled ( $12 \mathrm{~h}$ light-12 h dark). Rats were placed in wire-mesh cages and GF and HE rats were kept in isolators (La Calhene, France); one isolator was used for each bacterial status.

\section{Diets}

Two diets were used: a control diet containing ( $\mathrm{g} / \mathrm{kg}$ ) cooked potatoes 460 , fish meal 230 , lard 100 , cellulose 50 , maize oil 40 , mineral and vitamin mixture (composition previously described by Andrieux \& Sacquet, 1986) 20, and sucrose 100, and an experimental diet in which $100 \mathrm{~g}$ sucrose $/ \mathrm{kg}$ was replaced by $100 \mathrm{~g}$ inulin $/ \mathrm{kg}$ extracted from chicory and provided by ARD, Paris, France. Sterilized feed ( $\gamma$ irradiation, $45 \mathrm{kGy}$ in vacuum-sealed plastic bags) and water were given ad libitum to the rats. 


\section{Experimental design}

Groups of ten GF rats and ten HE rats were used; five rats were fed for 1 month on the control diet, five on the experimental diet. At the end of this adaptation period the rats were killed by an overdose of sodium pentobarbitone (SANOFI, Aulnay/Bois, France: $60 \mathrm{mg} / \mathrm{kg}$ intraperitoneally). Caecal $\mathrm{pH}$ was measured. The caecum and colon were then removed with their contents. A portion of the caecal contents $(1 \mathrm{~g})$ was frozen with liquid $\mathrm{N}_{2}$ and maintained at $-20^{\circ}$ until required for metabolite determination. For each group of rats the remaining caecal contents and colonic contents were separated from the mucosa by injecting into the hindgut lumen a $\mathrm{NaCl}(9 \mathrm{~g} / \mathrm{l})-\mathrm{EDTA}(2 \mathrm{mM})$ buffer containing bacterial protease inhibitors ( $\mathrm{Na}$ azide $0.02 \mathrm{~g} / 1$, phenylmethylsulphonyl fluoride $0.1 \mathrm{~mm}$ ) and pooled. The mucosas from the caecum and the colon were scraped with a histological slide and collected separately. The water-soluble mucin fractions were extracted from the pooled caecal and colonic contents and from caecal and colonic mucosal scrapings.

\section{Extraction of water-soluble mucins from the samples}

The methodology already described (Fontaine \& Meslin, 1994) was slightly modified from Miller \& Hoskins (1981). Each sample was homogenized, then centrifuged. The supernatant fraction was precipitated with ethanol; the pellet was dialysed against distilled water and lyophilized. The weight and protein composition of the lyophilized powder were determined by a modified Lowry method (Bensadoun \& Weinstein, 1976). The total weight of mucin was corrected by taking into account the $1 \mathrm{~g}$ of caecal contents removed for metabolite determination.

Neutral, acidic (sialomucins and sulphomucins) and strictly sulphated mucins (sulphomucins) were characterized by transposing the tests used in histochemistry to the mucins of the intestinal globlet cells, as previously described (Fontaine \& Meslin, 1994). The initial samples consisted of $1 \mathrm{mg}$ of the lyophilized powder dissolved in $1 \mathrm{ml}$ of distilled water. This was diluted to $0.025-0.150 \mathrm{mg} / \mathrm{ml}$ for neutral mucin determination and to $0.1-0.5 \mathrm{mg} / \mathrm{ml}$ for acidic and sulphated mucins; histochemical reagents (periodic acid-Schiff (PAS) pH 7, or alcian blue (AB) pH 2.5 or AB pH 0.5 respectively) were added, and the $\mathrm{pH}$ adjusted as required. Acidic mucins were precipitated in the presence of modified Carnoy fixative (ethanol $(950 \mathrm{ml} / 1)$-formaldehyde $(350 \mathrm{ml} / 1)$-acetic acid $(6: 3: 1$, by vol.)). Centrifugation was carried out at $9500 \mathrm{~g}$ for $10 \mathrm{~min}$. The pellet was dissolved at the convenient $\mathrm{pH}$ in the presence of Triton X100 and sonicated for 1 min (Bransonic 52 tank, Biobloc Scientific, Paris, France). Absorbance was read with a Shimatsu spectrophotometer (Roucaire, Vélizy, France) at $600 \mathrm{~nm}$ for the $\mathrm{AB}$ and at $570 \mathrm{~nm}$ for the PAS reaction.

\section{Interference by dietary compounds}

Interference of dietary compounds present in the intestinal luminal contents was tested by treating a portion of the diet in the same manner as the intestinal contents or mucosal scrapings.

\section{Electrophoretic controls}

As in the previous paper (Fontaine \& Meslin, 1994), electrophoretic controls were used (results not shown) to verify that protein contaminants, if present, did not interfere with mucin determination.

\section{Bacterial metabolite analysis}

SCFA were analysed, using GLC after water extraction of acidified samples (Andrieux et al. 1991). D and L-lactic acids were determined enzymically (UV Boehringer method, Meylan, France). 
Table 1. Body weight, caecal weight and pH, and short-chain fatty acid (SCFA) composition in germ-free and heteroxenic rats fed on control or inulin-containing diets* (Mean values with their standard errors for five rats per group)

\begin{tabular}{|c|c|c|c|c|c|c|c|c|}
\hline \multirow{3}{*}{ Diet... } & \multicolumn{4}{|c|}{ Germ-free rats } & \multicolumn{4}{|c|}{ Heteroxenic rats } \\
\hline & \multicolumn{2}{|c|}{ Control } & \multicolumn{2}{|c|}{ Inulin } & \multicolumn{2}{|c|}{ Control } & \multicolumn{2}{|c|}{ Inulin } \\
\hline & Mean & $\mathbf{S E}$ & Mean & $\mathbf{S E}$ & Mean & SE & Mean & SE \\
\hline Body wt (g) & $329^{\mathrm{a}}$ & 27 & $300^{\mathrm{a}}$ & 12 & $311^{3}$ & 12 & $308^{a}$ & 9 \\
\hline Caecal wt (g) & $16 \cdot 2^{\mathrm{a}}$ & $2 \cdot 5$ & $16 \cdot 1^{a}$ & 1.5 & $3 \cdot 7^{\mathrm{c}}$ & 0.4 & $6 \cdot 5^{b}$ & 0.7 \\
\hline Caecal pH & $7 \cdot 6^{\mathrm{a}}$ & 0.1 & $7.3^{\mathrm{a}}$ & 0.1 & $6.6^{\mathrm{b}}$ & 0.1 & $6.3^{\mathrm{c}}$ & $0 \cdot 1$ \\
\hline Total SCFA ( $\mu \mathrm{mol})$ & $40 \cdot 5^{c}$ & $3 \cdot 5$ & $37 \cdot 0^{\mathrm{c}}$ & $2-0$ & $104 \cdot 7^{b}$ & $3-6$ & $221 \cdot 0^{\mathrm{a}}$ & 1.7 \\
\hline $\begin{array}{l}\text { SCFA ( } \mu \text { mol } / \mathrm{g} \text { caecal } \\
\text { content) }\end{array}$ & $2 \cdot 5^{c}$ & 1.0 & $2 \cdot 3^{c}$ & 0.5 & $28 \cdot 3^{\mathrm{b}}$ & $3 \cdot 2$ & $34 \cdot 0^{\mathrm{a}}$ & 1.0 \\
\hline Acetate (\%) & 100 & & 100 & & 64 & & 64 & \\
\hline Propionate (\%) & - & & - & & 21 & & 22 & \\
\hline Butyrate $(\%)$ & - & & - & & 7 & & 12 & \\
\hline Valerate (\%) & - & & - & & 2 & & 0 & \\
\hline Isoacids (\%) & - & & - & & 6 & & 0 & \\
\hline Total lactate $(\mu \mathrm{mol})$ & - & & - & & $7 \cdot 4^{\mathrm{b}}$ & 0.5 & $17.6^{\mathrm{a}}$ & $1 \cdot 1$ \\
\hline $\begin{array}{l}\text { Lactate }(\mu \mathrm{mol} / \mathrm{g} \text { caecal } \\
\text { content) }\end{array}$ & - & & 一 & & $2 \cdot 0^{b}$ & 0.1 & $2 \cdot 7^{\mathrm{a}}$ & $0 \cdot 3$ \\
\hline L-Lactate (\%) & - & & - & & 71 & & 61 & \\
\hline D-Lactate (\%) & - & & - & & 29 & & 39 & \\
\hline
\end{tabular}

a, b, c Mean values within a row with unlike superscript letters were significantly different, $P<0.05$.

* For details of diets and procedures, see pp. 882-883.

Table 2. Weight and protein content of lyophilized mucin powder from the caecal and colonic contents and mucosa of germ-free and heteroxenic rats fed on control or inulin-containing diets*

\begin{tabular}{|c|c|c|c|}
\hline & Weight (mg) & Protein content $(\mathrm{mg})$ & Mucin (mg/mg protein) \\
\hline \multicolumn{4}{|l|}{ Germ-free rats $(n 5)$} \\
\hline \multicolumn{4}{|l|}{ Contents } \\
\hline Caecum, control diet & 283 & $2 \cdot 6$ & 108.8 \\
\hline Caecum, inulin diet & 266 & 3.4 & $78 \cdot 2$ \\
\hline Colon, control diet & 34 & 0.7 & $48 \cdot 6$ \\
\hline Colon, inulin diet & 34 & 0.5 & 68.0 \\
\hline \multicolumn{4}{|l|}{ Mucosa } \\
\hline Caecum, control diet & 6.0 & $1 \cdot 2$ & $5 \cdot 0$ \\
\hline Caecum, inulin diet & 6.6 & 1.8 & 3.7 \\
\hline \multicolumn{4}{|l|}{ Heteroxenic rats $(n 5)$} \\
\hline \multicolumn{4}{|l|}{ Contents } \\
\hline Caecum, control diet & $46 \cdot 4$ & $8 \cdot 8$ & $5 \cdot 3$ \\
\hline Caecum, inulin diet & 58.6 & $10 \cdot 2$ & $5 \cdot 7$ \\
\hline Colon, control diet & 22.5 & $4 \cdot 0$ & 5.6 \\
\hline Colon, inulin diet & $25 \cdot 0$ & $5 \cdot 0$ & 5.0 \\
\hline \multicolumn{4}{|l|}{ Mucosa } \\
\hline Caecum, control diet & 39.9 & $27 \cdot 5$ & 1.5 \\
\hline Caecum, inulin diet & $40 \cdot 0$ & $28 \cdot 8$ & $1 \cdot 4$ \\
\hline Colon, control diet & $106 \cdot 3$ & $73 \cdot 5$ & $1 \cdot 4$ \\
\hline Colon, inulin diet & 2.5 & 1.5 & 1.7 \\
\hline
\end{tabular}

* For details of diets and procedures, see pp. 882-883.

$\dagger$ Colonic mucosas were not determined in the germ-free group due to technical difficulties. 

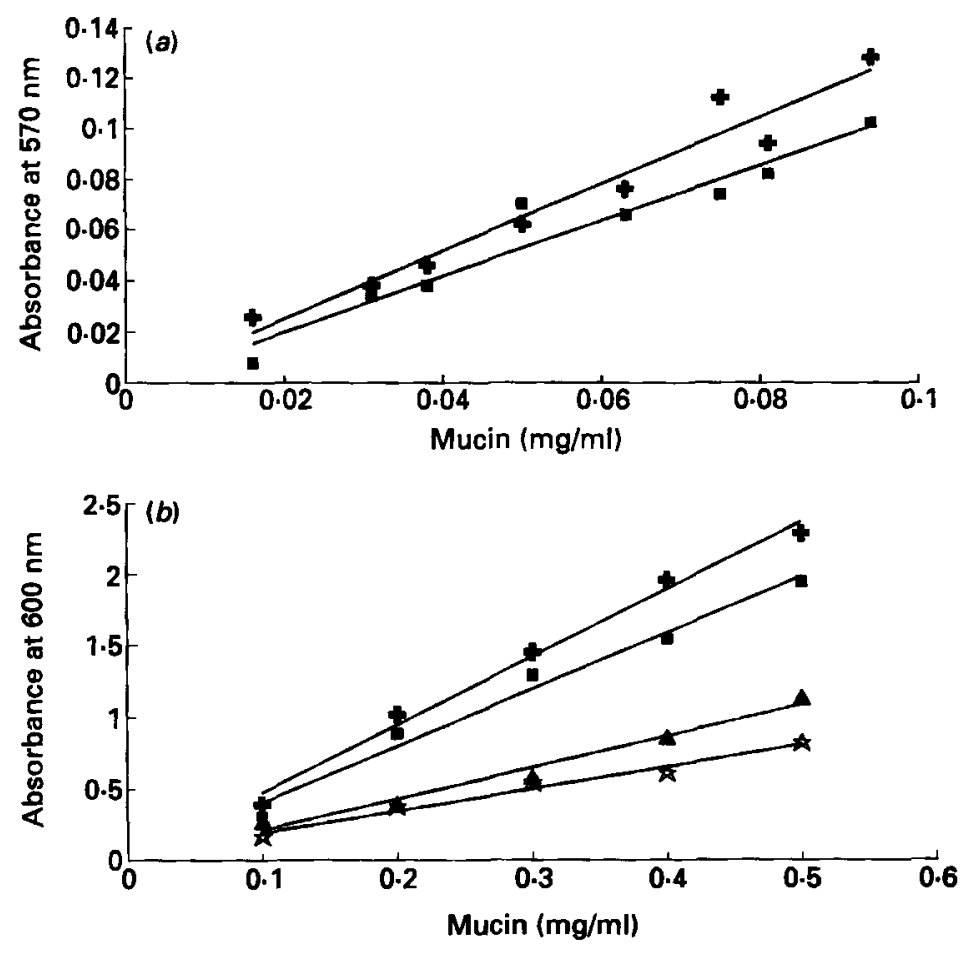

Fig. 1. Spectrocolorimetric assays of (a) neutral mucin and (b) acidic and sulphated mucins in the colonic contents of germ-free rats fed on a control diet or an inulin-containing diet. Panel (a): (a), neutral mucin, control; ( $\$$ ), neutral mucin, inulin. Panel (b): (口), acidic mucin, control; (\$), acidic mucin, inulin; ( 4 ), sulphated mucin, control; (A), sulphated mucin, inulin.

\section{Statistical analysis}

For each group the results from individual rats were expressed as means with their standard errors. Experimental values were compared by ANOVA and Newman-Keuls multiplerange tests; the slopes of the assays for each mucin type were compared by linear regression coefficient analysis (STATITCF software; ITCF, Paris, France).

\section{RESULTS}

Body weight, caecal weight and caecal metabolite concentration (Table I)

Body weight was similar in all groups (mean 312 (SE 10) g). Germ-free rats were characterized by a large caecum $(16 \mathrm{~g})$, an approximately neutral caecal $\mathrm{pH}$ and a very low SCFA concentration $(2.5 \mu \mathrm{mol}$ acetate $/ \mathrm{g})$. Inulin in the diet did not modify these values.

In HE rats fed on the control diet the mean caecal weight was only $3.7 \mathrm{~g}$, the caecal $\mathrm{pH}$ was slightly acidic (6.6), the concentration of SCFA was about $28 \mu \mathrm{mol} / \mathrm{g}$ and that of lactic acid $2 \mu \mathrm{mol} / \mathrm{g}$ caecal content. Inulin in the diet doubled the caecal weight in $\mathrm{HE}$ rats, significantly reduced the $\mathrm{pH}$ (to 6.3) and significantly increased the amount and concentration of total SCFA and lactic acid. The SCFA and lactic acid profiles also changed: the proportion of butyrate was enhanced whereas valerate and caproate disappeared and the proportion of L-lactic acid was lowered. 
Table 3. Mucin distribution in contents and mucosa from the caecum and colon of germfree and heteroxenic rats fed on control or inulin-containing diets*

(Calculated slopes of the spectrocolorimetric assays from $1 \mathrm{mg}$ lyophilized mucin powder)

\begin{tabular}{|c|c|c|c|}
\hline Mucin type... & Neutral (PAS +) & Acidic (AB 2.5+) & Sulphated (AB $0.5+)$ \\
\hline \multicolumn{4}{|l|}{ Germ-free rats } \\
\hline \multicolumn{4}{|l|}{ Contents } \\
\hline Caecum, control diet & 1.25 & $4 \cdot 50$ & $1 \cdot 33$ \\
\hline Caecum, inulin diet & 1.59 & 4.08 & 1.42 \\
\hline Colon, control diet & 1.09 & $4 \cdot 02$ & 1.67 \\
\hline Colon, inulin diet & 1.32 & 4.73 & $2 \cdot 19$ \\
\hline \multicolumn{4}{|l|}{ Mucosa } \\
\hline Caecum, control diet & 1.89 & 1.77 & 1.74 \\
\hline Caecum, inulin diet & 2.87 & 2.34 & 1.88 \\
\hline \multicolumn{4}{|l|}{ Heteroxenic rats } \\
\hline \multicolumn{4}{|l|}{ Contents } \\
\hline Caecum, control diet & 3.10 & $15 \cdot 3$ & 0.34 \\
\hline Caecum, inulin diet & 3.44 & $12 \cdot 0$ & 0.42 \\
\hline Colon, control diet & $2 \cdot 40$ & 15.4 & 0.66 \\
\hline Colon, inulin diet & $3 \cdot 70$ & $13 \cdot 8$ & 0.85 \\
\hline \multicolumn{4}{|l|}{ Mucosa } \\
\hline Caecum, control diet & 2.82 & $5 \cdot 48$ & 0.80 \\
\hline Caecum, inulin diet & $2 \cdot 50$ & $2 \cdot 60$ & 1.03 \\
\hline Colon, control diet & 1.80 & 4.03 & 0.80 \\
\hline Colon, inulin diet & $2 \cdot 70$ & 1.82 & $1 \cdot 34$ \\
\hline
\end{tabular}

PAS, periodic acid-Schiff reagent; $A B$, alcian blue reagent.

* For details of diets and procedures, see pp. 882-885.

$\uparrow$ Colonic mucosas were not determined in the germ-free group due to technical difficulties.

Amounts of mucin powder and corresponding proteins in caecal and colonic luminal contents and in mucosas (Table 2)

The amount of crude mucin obtained from the caecal contents of GF rats $(283 \mathrm{mg})$ was fivefold higher than in $\mathrm{HE}$ rats $(46.4 \mathrm{mg})$. On the other hand, a lower amount of mucin was found in the caecal mucosa of GF rats: $6 \mathrm{mg}$, instead of $40 \mathrm{mg}$ in the caecal mucosa of $\mathrm{HE}$ rats. It should be noted that we could not obtain enough powder for analysis from the colonic mucosa in the groups of five GF rats. Inulin in the diet tended to decrease the amount of mucin in caecal contents of GF rats but enhanced that of $\mathrm{HE}$ rats; it did not modify the amount of mucin in the caecal mucosa. The colon of GF rats, like the caecum, contained more mucin than the colon of HE rats. Inulin had no effect on the amount of mucin in the colonic luminal contents but it reduced strongly the amount of mucin in the mucosa of $\mathrm{HE}$ rats.

The mean ratios $(w / w)$ of protein expressed per total mucin weight were 23.5 and $67.5 \%$ in mucosal scrapings from GF and HE rats respectively. They were tenfold lower in caecal and colonic contents of GF rats and fivefold lower in these samples from HE rats. Protein contents of the mucin samples were not affected by the diet.

\section{Mucin-type determination}

Dietary inulin still present in the caecal and the colonic contents was washed away during dialysis. The artefact in the mucin assay due to other residual dietary compounds was 0.01 absorbance units $/ \mathrm{mg}$ for the neutral mucin, 0.02 absorbance units $/ \mathrm{mg}$ for the acid mucin 

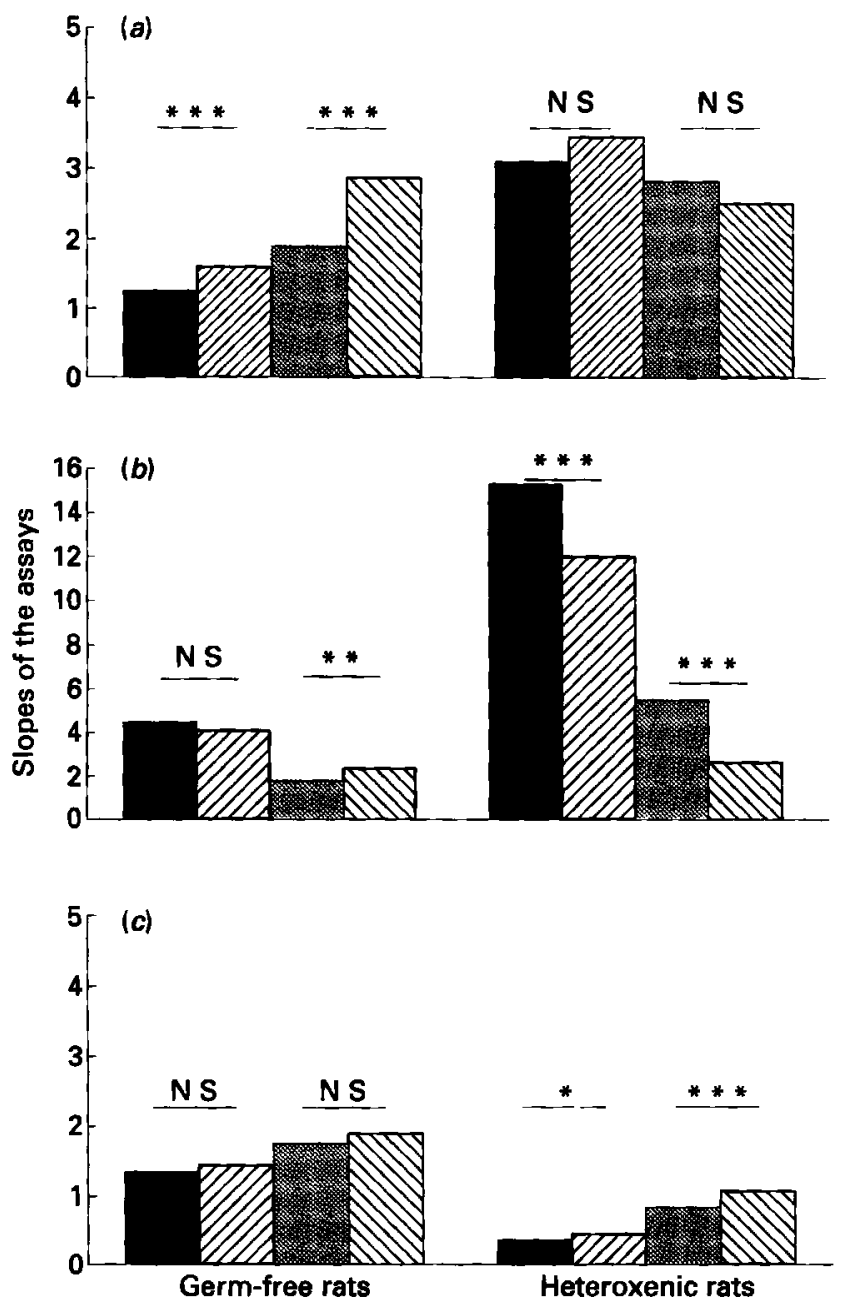

Fig. 2. Slopes of the assays of (a) caecal neutral mucins, (b) caecal acidic mucins and (c) caecal sulphated mucins in the contents $(\square, Z)$ and mucosa $($ 圈, $\$)$ of germ-free and heteroxenic rats fed on a control diet $(\square$, 图) or an inulin-containing diet $(\square, \mathbb{Q})$. Mean values were significantly different for the two diets: ${ }^{*} P<0.05,{ }^{* *} P<0.01$, $* * * P<0.001$

and 0.05 absorbance units $/ \mathrm{mg}$ for the sulphated mucin. The very small size of these values did not affect comparison between the two diets, particularly for acidic and sulphated mucins (Fig. 1(b)).

Fig. 1 shows assays of neutral (a), and acidic and sulphated (b) mucins in the colonic contents of the GF rats fed on control or inulin-containing diets. All other samples were treated in the same manner (results not shown). There was a linear relationship between absorbance and the semi-purified mucin concentration $(\mathrm{mg} / \mathrm{ml})$ for each mucin type characterized. The slopes of the curves were calculated from these results (Table 3). Bar graphs (Figs. 2 and 3) compare each mucin between experimental treatments (e.g. inulin diet $v$. control diet in the contents or in the mucosa) in GF or HE rats, and refer to the absorbance for $1 \mathrm{mg}$ mucin. 

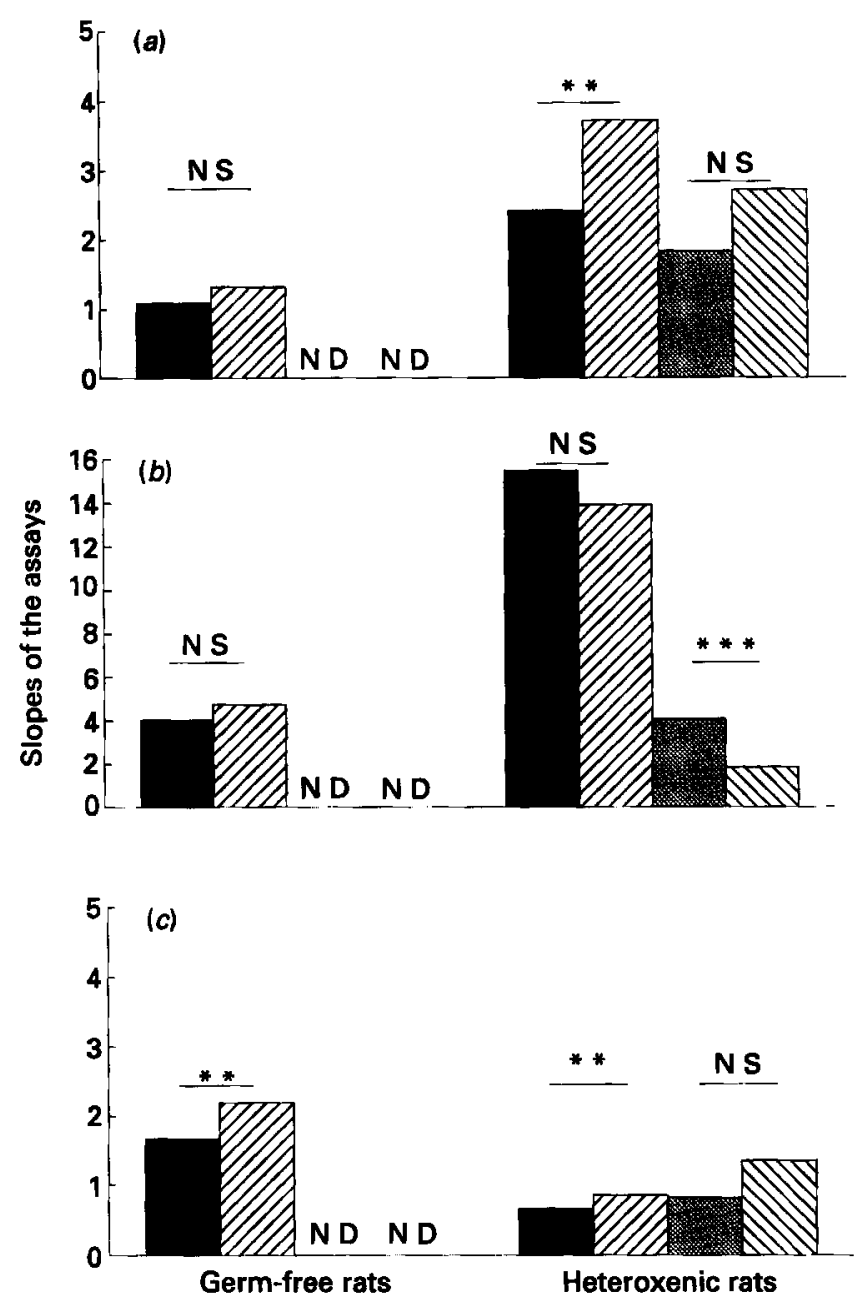

Fig. 3. Slopes of the assays of (a) colonic neutral mucins, (b) colonic acidic mucins and (c) colonic sulphated mucins in the contents $(\square, \square)$ and mucosa $(0, \mathbb{0}, \mathbb{0})$ of germ-free and heteroxenic rats fed on a control diet $(\square$, ) or an inulin-containing diet $(\square, \mathbb{Q})$. Mean values were significantly different for the two diets: ${ }^{* *} P<0.01$, *** $P<0.001$. ND, not determined.

Caecal neutral mucins in GF rats were significantly increased both in the contents and in the mucosa under an inulin-containing diet. Caecal contents of $\mathrm{HE}$ rats contained three times as much caecal neutral mucin as those of the GF group, whereas inulin affected neither the contents nor the mucosa (Fig. 2(a)).

The variations of caecal acidic mucins (Fig. 2(b)) were very different from those of neutral mucins. In GF rats, inulin had no effect on the contents, and significantly increased acidic mucins in the mucosa, although this increase was low. Values in HE rat contents were about four times as high as those in GF rats, and dietary inulin significantly decreased acidic mucins in both the contents and the mucosa (Fig. 2(b)).

The caecal sulphated mucins (Fig. 2(c)) in GF rats were not modified by dietary inulin either in the contents or in the mucosa. HE rats responded differently: dietary inulin increased sulphated mucins both in the contents and in the mucosa; however, this increase 
was larger in the mucosa than in the contents. The values in the $\mathrm{HE}$ rat contents and mucosa were twice as low as in the GF rats.

Inulin did not affect the amount of colonic neutral mucin in the contents of the GF rats (Fig. 3(a)). On the other hand, it significantly increased neutral mucins in the colonic contents of HE rats but did not affect their mucosa. Colonic content values were twice as high in HE rats as in GF rats.

The colonic acidic mucins (Fig. 3(b)) in the GF rat contents did not differ from the caecal acidic mucins and dietary inulin was without effect. In the $\mathrm{HE}$ rats the control diet yielded colonic content values similar to the caecal content values. Inulin had no effect on the acidic mucins in the contents, but reduced significantly the acidic mucins in the colonic mucosa, similarly to what was observed in the caecal mucosa.

The effect of inulin on the colonic sulphated mucins (Fig. 3(c)) in the contents of the GF rats was different from that observed in the caecum: sulphated mucins increased significantly. In the HE rats sulphated mucins increased significantly in the colonic contents under an inulin diet whereas inulin did not affect sulphated mucins in the mucosa.

\section{DISCUSSION}

Our results show that the amount of mucin and its distribution according to histochemical staining differed strongly between GF and HE rats, both within luminal contents and in the mucosa. The greater amount of mucin collected from the caecal contents of the GF rats as compared with that of $\mathrm{HE}$ rats (Table 2) confirms the previous findings of Hoskins \& Zamcheck (1968). This is due to the lack of degradation, i.e. of mucolytic activity, in the absence of microflora, as shown previously (Meslin et al. 1993). The accumulation of mucin is believed to hinder water absorption and contribute to the caecal enlargement (Asano, 1967; Donowitz \& Binder, 1979). However, although the caecal volume of GF rats was five time as large as in HE rats (Table 1), the amount of mucin in the present experiment was also five times as large. This suggests that caecal mucin concentrations are quite similar in GF and HE rats. Moreover Enss et al. (1992) found similar amounts of mucin in colonic contents of GF and specific-pathogen-free rats.

In a previous study using a pilocarpin treatment, Fontaine \& Meslin (1994) collected the intestinal mucin of GF rats from both mucosa and lumen of the small intestine and of the hindgut. Mucin was distributed into the following types (absorbance units $/ \mathrm{mg}$ ): 3.26 neutral mucin, 4.43 sialomucin and 1.85 sulphomucin. Furthermore this mucin was in fact a mixture of mucin discharged from the mucosa to the lumen as a result of pilocarpin treatment and of mucin normally present in the luminal contents collected from the small intestine and the hindgut. Therefore, the mucin type proportions in this previous study, like those of the present study, differed according to anatomical site and to whether mucosal or luminal contents were considered. Colonic mucin in several species differs from mucin in the proximal intestine by its greater proportion of acidic mucin (Allen et al. 1982). This suggests that, because bacterial degradation was absent in GF rats, the local composition of luminal mucin represents both the local secretion from the mucosa and the accumulation of the fraction secreted from the upper parts of the gastrointestinal tract.

The caecal contents of GF rats in the present study also contained more acidic mucins than sulphated mucins. This was due to sialomucins: the $\mathrm{AB}$ pH 2.5 reaction we used detected both sialylated and sulphated mucins and the $\mathrm{AB} \mathrm{pH} 0.5$ reaction only the strictly sulphated mucins. Sialomucins might be obtained as the difference between these two values. The caecal and colonic mucosas of GF rats were characterized by a very low amount of mucin and low number of mucin-containing cells (Meslin et al. 1993).

The mean percentage of protein in the caecal mucosal scraping of GF rats was similar 
to the value found by Slayter et al. (1991). Surprisingly, we found a much lower percentage of protein in caecal and colonic contents of GF rats. As endogenous proteases efficiently hydrolyse mucin proteins (Allen et al. 1982; Pasquier \& Vatier, 1990), this may be due to the greater endogenous proteolytic activity in the large intestine of GF rats than in conventional rats (Reddy et al. 1968).

Our mucin preparation was not contaminated by carbohydrates from the diet present in the intestinal contents, since very little staining was found when diet was treated as mucin. Mucolytic activities were found in the caecal content of $\mathrm{HE}$ rats showing that bacteria from humans can degrade carbohydrate chains of rat mucin (Meslin et al. 1993). Consequently, the luminal mucin composition in $\mathrm{HE}$ rats resulted from local and proximal intestinal secretions, as in GF rats, in addition to bacterial degradation. It has been shown that mucin plays an important role as a bacterial substrate in the colon (Flourie et al. 1991) and that many bacteria from the intestinal microflora are capable of degrading mucus glycoproteins (Salyers et al. 1977). Some bacteria such as Bifidobacterium bifidum use mucus as their sole source of energy (Miller \& Hoskins, 1981) whereas the mucin pattern is not affected by others such as Peptostreptococcus when they are inoculated into the GF rat (Gustafsson et al. 1981).

Staining with $\mathrm{AB}$ pH 2.5, which stains total acidic mucins, was more intense in $\mathrm{HE}$ rats than in GF rats. More intense staining was also observed for neutral mucins, but not for sulphated mucins. Szentkuti et al. (1990), using histochemical methods, observed a stronger stainability of all mucin types in conventional rats than in GF rats, whereas Enss et al. (1992), using ion-exchange chromatography, confirmed that relative amounts of acidic mucins are higher in specific-pathogen-free rats.

Results obtained with the inulin diet confirm that intestinal fermentation, which did occur as demonstrated by the metabolites produced (Table 1), can alter the composition of mucosal mucins. Adding inulin to the diet of GF rats increased caecal neutral mucins both in the contents and mucosa, increased caecal acidic mucins in the mucosa, and increased colonic sulphated mucins in the contents. Adding inulin to the diet of HE rats decreased caecal acidic mucins both in the contents and in the mucosa. This decrease affected sialomucins since sulphated mucins were slightly enhanced. Inulin increased neutral mucins in the contents of the HE rat colon, decreased acidic mucins in its mucosa and increased sulphated mucins in its contents. These variations might be related to the bacterial metabolites produced in the contents and absorbed by the mucosa. Inulin actually decreased the amount of mucin in the colonic mucosa (Table 2). This suggests that inulin fermentation induced a release of mucin into the gut lumen. Inulin increased total SCFA and total lactate, thereby significantly reducing the $\mathrm{pH}$ (Table 1). Acidification of intestinal contents has been shown to stimulate mucus secretion, while SCFA behave in a more complex way. Sakata \& Engelhardt (1981), using solutions of SCFA of various osmolalities, demonstrated that low osmolality causes a considerable release of mucins from goblet cells both in the proximal and distal colon, and that the lower the osmolality the larger the amount of mucin released. However, the main effect of the inulin diet was an increase of sulphomucin together with a reciprocal decrease of sialomucin in the caecal and colonic mucosas. These variations are important to consider, as it has been reported that sulphomucin can increase potential resistance to attacks by bacterial enzymes (Rhodes, 1989). In GF rats, Enss et al. (1994) recently observed that a mechanical challenge causes alterations of rat colonic mucosa and released mucins. In conventional rats fed with several insoluble or soluble dietary fibres, Cassidy et al. (1990) and Satchithanandam et al. (1990) also observed an increase in the proportion of sulphomucin and the amount of total mucin in the small intestine and in the colon. These authors postulated that the change in mucin composition contributed to the protective effect of dietary fibres in the incidence of colon 
cancer. In conclusion, inulin may have a beneficial effect on health by stimulating sulphomucin synthesis; however, a low amount of mucin in the colon may be considered less beneficial for the mucosal physiology.

\section{$\mathrm{Ph}$ Butler (INRA translation and terminology service) improved the English manuscript.}

\section{REFERENCES}

Allen, A., Bell, A., Mantle, M. \& Pearson, J. P. (1982). The structure and physiology of gastrointestinal mucus. In Mucus in Health and Disease, vol. 2, pp. 115-133 [E. Chantler, J. Elder and M. Elstein, editors]. New York: Plenum Press.

Andremont, A., Raibaud, P., Tancrède, C., Duval-Iflah, Y. \& Ducluzeau, R. (1985). The use of germ-free mice associated with human fecal flora as an animal model to study enteric bacterial interactions. In Bacterial Diarrhea Diseases, vol. 4, pp. 219-228 [Y. Takeda and T. Miwatani, editors]. Tokyo: KTK Scientific Publishers.

Andrieux, C. \& Sacquet, E. (1986). Effects of amylomaize starch on mineral metabolism in the adult rat: role of the microflora. Journal of Nutrition 116, 991-998.

Andrieux, C., Lory, S., Dufour-Lescoat, C., De Baynast, R. \& Szylit, O. (1991). Physiological effect of inulin in germ-free rats and in heteroxenic rats inoculated with a human flora. Food Hydrocolloids 5, 49-56.

Asano, T. (1967). Inorganic ions in cecal content of gnotobiotic rats. Proceedings of the Society for Experimental Biology and Medicine 124, 424-430.

Bacon, J. S. D. \& Edelman, J. (1951). The carbohydrates of Jerusalem artichoke and other compositae. Biochemical Journal 48, 114-126.

Bensadoun, A. \& Weinstein, D. (1976). Assay of protein in the presence of interfering materials. Analytical Biochemistry 70, 241-250.

Cassidy, M. M., Lightfoot, F. G., Grau, L. E., Story, J. A., Kritchevsky, D. \& Vahouny, G. V. (1981). Effect of chronic intake of dietary fibers on the ultrastructural topography of rat jejunum and colon: a scanning electron microscopy study. American Journal of Clinical Nutrition 34, 218-228.

Cassidy, M. M., Satchithanandam, S., Calvert, R. J., Vahouny, G. V. \& Leeds, A. R. (1990). Quantitative and qualitative adaptations in gastrointestinal mucin with dietary fiber feeding. In Dietary Fiber: Chemistry, Physiology and Health Effects, pp. 67-88 [D. Kritchevsky, C. Bonfield and J. W. Anderson, editors]. New York and London: Plenum Press.

Cole, C. B., Fuller, R., Mallett, A. K. \& Rowland, I. R. (1985). The influence of the host on expression of intestinal microbial enzyme activities involved in the metabolism of foreign compounds. Journal of Applied Bacteriology 59, 549-553.

Debure, A., Colombel, J. F., Flourié, B., Rautureau, M. \& Rambaud, J. C. (1989). Comparaison de l'implantation et de l'activité métabolique d'une flore fécale de rat et d'une flore fécale humaine inoculées chez le rat axénique (Implantation and metabolic activity of rat and human faecal bacterial flora administered to germ-free rats). Gastroentérologie Clinique et Biologique 13, 25-31.

Dirks, P. \& Freeman, H. J. (1987). Effects of differing purified cellulose, pectin and hemicellulose fiber diets on mucosal morphology in the rat small and large intestine. Clinical and Investigative Medicine 10, 32-38.

Donowitz, M. \& Binder, H. J. (1979). Mechanism of fluid and electrolyte secretion in the germ-free rat cecum. American Journal of Digestive Diseases 24, 551-559.

Ecknauer, R., Sircar, B. \& Johnson, L. R. (1981). Effect of dietary bulk on small intestinal morphology and cell renewal in the rat. Gastroenterology $81,781-786$.

Enss, M. L., Grosse-Siestrup, H., Schmidt-Wittig, U. \& Gärtner, K. (1992). Changes in the colonic mucins of germ-free rats in response to the introduction of a normal rat microbial fiora. Joumal of Experimental Animal Science 35, 110-119.

Enss, M. L., Schmidt-Wittig, U., Höner, K., Kownatzki, R. \& Gärtner, K. (1994). Mechanical challenge causes alterations of rat colonic mucosa and released mucins. Journal of Experimental Animal Science 36, $128-140$.

Filipe, I. (1979). Mucins in the human gastrointestinal epithelium: a review. Investigations in Cell Pathology 2, $195-216$.

Flouriè, B., Pellier, P., Florent, C., Marteau, P., Pochart, P. \& Rambaud, J. C. (1991). Site and substrate for methane production in human colon. American Journal of Physiology 260, G752-G757.

Fontaine, N. \& Meslin, J. C. (1994). Mise au point d'un dosage sélectif des différents types de mucines gastrointestinales: utilisation de réactifs histochimiques (Spectrocolorimetric assay for the 3 types of gastrointestinal mucin using histochemical stains). Reproduction, Nutrition, Développement 34, 237-247.

Gustafsson, B. E., Carlstedt-Duke, B. \& Nord, C. E. (1981). Mucosal related intestinal bacteria and host metabolism. In Recent Advances in Germfree Research. Proceedings of the VIIth International Symposium on Gnotobiology, pp. 249-254 [S. Sasaki, A. Ozawa and K. Hashimoto, editors]. Tokyo: Tokai University Press.

Hoskins, L. C. \& Zamcheck, N. (1968). Bacterial degradation of gastrointestinal mucins: I. Comparison of mucus constituents in the stools of germ-free and conventional rats. Gastroenterology 54, 210-217. 
Huang, C. B., Lundin, E., Zhang, J. X., Stenling, R., Hallmans, G. \& Reuterving, C. O. (1990). Dietary fibre and colonic mucin change in golden hamster. A morphometrical and histochemical study. In Dietary Fibre: Chemical and Biological Aspects, pp. 243-247 [D. A. T. Southgate, K. Waldron, I. T. Johnson and G. R. Fenwick, editors]. Cambridge: Royal Society of Chemistry/Norwich: AFRC Institute of Food Research.

Komai, M. \& Kimura, S. (1980). Gastrointestinal responses to graded levels of cellulose feeding in conventional and germ-free mice. Journal of Nutritional Science and Vitaminology 26, 389-399.

Mallett, A. K., Bearne, C. A., Rowland, I. R., Farthing, M. C. G., Cole, C. B. \& Fuller, R. (1987). The use of rats associated with a human fecal flora as a model for studying the effects of diet on the human gut microflora. Journal of Applied Bacteriology 63, 39-45.

Meslin, J. C., Andrieux, C., Sakata, T., Beaumatin, P., Bensaada, M., Popot, F., Szylit, O. \& Durand, M. (1993). Effects of galacto-oligosaccharide and bacterial status on mucin distribution in mucosa and on large intestine fermentation in rats. British Journal of Nutrition 69, 903-912.

Miller, R. S. \& Hoskins, L. C. (1981). Mucin degradation in human colon ecosystems. Fecal population densities of mucin-degrading bacteria estimated by a 'most probable number' method. Gastroenterology 81, 759-765.

Nilsson, U. \& Björck, J. (1988). Availability of cereal fructans and inulin in the rat intestinal tract. Journal of Nutrition 118, 1482-1486.

Nilsson, U., Öste, R., Jägerstad, M. \& Birkhed, D. (1988). Cereal fructans: in vitro and in vivo studies on availability in rats and humans. Journal of Nutrition 118, 1325-1330.

Pasquier, M. C. \& Vatier, J. (1990). Mucus gastro-intestinal: une barrière protectrice complexe (Gastrointestinal mucus: a complex protective barrier). Gastroentérologie Clinique et Biologique 14, 352-365.

Reddy, B. S., Pleasants, J. R. \& Wostmann, B. S. (1968). Effect of dietary carbohydrates on intestinal disaccharidases in germ-free and conventional rats. Journal of Nutrition 95, 413-419.

Rhodes, J. M. (1989). Colonic mucus and mucosal glycoproteins: the key to colitis and cancer? Gut 30, $1660-1666$.

Rumessen, J. J., Bode, S., Hamberg, O. \& Gudmand-Hoyer, E. (1990). Fructans of Jerusalem artichokes: intestinal transport, absorption, fermentation and influence on blood glucose, insulin and $\mathrm{C}$ peptide responses in healthy subjects. American Journal of Clinical Nutrition 52, 675-681.

Sakata, T. (1987). Stimulatory effect of short-chain fatty acids on epithelial cell proliferation in the rat intestine: a possible explanation for trophic effects of fermentable fibre, gut microbes and luminal trophic factors. British Journal of Nutrition 58, 95-103.

Sakata, T. \& Engelhardt, W. Von (1981). Influence of short-chain fatty acids and osmolality on mucin release in the rat colon. Cell and Tissue Research 219, 371-377.

Salyers, A. A., West, S. E. H., Vercellotti, J. R. \& Wilkins, T. D. (1977). Fermentation of mucus and plant polysaccharides by anaerobic bacteria from the human colon. Applied and Environmental Microbiology 34, 529-533.

Satchithanandam, S., Vargofcak-Apker, M., Calvert, R. J., Leeds, A. R. \& Cassidy, M. M. (1990). Alteration of gastrointestinal mucin by fiber feeding in rats. Journal of Nutrition 120, 1179-1184.

Slayter, H. S., Wold, J. K. \& Midtvedt, T. (1991). Intestinal mucin of germ-free rats. Biochemical and electronmicroscopic characterisation. Carbohydrate Research 222, 1-9.

Smith, A. C. \& Podolsky, D. K. (1986). Colonic mucin glycoproteins in health and disease. Clinics in Gastroenterology 15, 815-837.

Southon, S., Livesey, G., Gee, J. M. \& Johnson, I. T. (1985). Differences in intestinal protein synthesis and cellular proliferation in well nourished rats consuming conventional laboratory diets. British Journal of Nutrition 53 , 87-95.

Szentkuti, L., Riedesel, H., Enss, M.-L., Gaertner, K. \& Engelhardt, W. Von (1990). Pre-epithelial mucus layer in the colon of conventional and germ-free rats. Histochemical Journal 22, 491-497.

Turck, D., Feste, A. S. \& Lifschitz, C. H. (1993). Age and diet affect the composition of porcine colonic mucins. Pediatric Research 33, 564-567. 